\title{
MAST CELL SUBSETS AND NEUROPEPTIDES IN LEPROSY REACTIONS
}

\author{
Sérgio Luiz Gomes Antunes ${ }^{1,2}$, Yong Liang'2, José Augusto da Costa Neri 1,2, \\ Euzenir Nunes Sarno 1,2, Mary Haak-Frendscho², Olle Johansson ${ }^{2}$
}

\begin{abstract}
The immunohistochemical identification of neuropeptides (calcitonin gene-related peptide, vasoactive intestinal polypeptide, substance $P, \alpha$-melanocyte stimulating hormone and $\gamma$-melanocyte stimulating hormone) quantification of mast cells and their subsets (tryptase/chymase-immunoreactive mast cells = TCMC and tryptase-immunoreactive mast cells = TMC) were determined in biopsies of six patients with leprosy reactions (three patients with type I reaction and three with type II). Biopsies were compared with those taken from the same body site in the remission stage of the same patient. We found a relative increase of TMC in the inflammatory infiltrate of the reactional biopsies compared to the post-reactional biopsy. Also, the total number of mast cells and the TMC/TCMC ratio in the inflammatory infiltrate was significantly higher than in the intervening dermis of the biopsies of both periods. No significant difference was found regarding neuroptide expression in the reactional and post-reactional biopsies. The relative increase of TMC in the reactional infiltrates could implicate this mast cell subset in the reported increase of the immune response in leprosy reactions.
\end{abstract}

KEY WORDS: leprosy, neuropeptides, mast cells, tryptase, chymase.

Abbreviations: $\alpha-M S H$ : alpha-melanocyte stimulating hormone; BB: borderline borderline patient; BL: borderline lepromatous patient; CGRP: calcitonin gene-related peptide; ENL: erythema nodosum leprosum; $\gamma$-MSH: gammamelanocyte stimulating hormone; IFN- $\gamma$. interferon-gamma; LL: lepromatous lepromatous patient; MDT: multidrug therapy; SP: substance P; TCMC: tryptase ${ }^{+}$chymase $^{+}$mast cells; TIR: type I reactions; TIIR: type II reactions; TMC: tryptase ${ }^{+}$chymase- mast cells; TNF- $\alpha:$ : tumor necrosis factor alpha; VIP: vasoactive intestinal polypeptide.

\begin{abstract}
Mastócitos, subpopulações mastocitárias e neuropeptídios nas reações da hanseníase
RESUMO - A marcação imuno-histoquímica dos neuropeptídios (SP, $\alpha$-MSH e $\gamma$-MSH, CGRP, VIP) e a imunomarcação de mastócitos e suas subpopulações triptase-positivas e triptase/quimase positivas foram realizadas em biópsias cutâneas de seis pacientes com reações hansenianas (três reações reversas e três eritema nodosos). A imunorreatividade nessas biópsias foi comparada com a obtida nas biópsias após a remissão das reações. Foi encontrado aumento relativo de mastócitos triptase-positivos no interior do infiltrado inflamatório das biópsias reacionais quando comparadas com as biópsias pós-reacionais. Além disso, o número total de mastócitos e o número relativo de mastócitos triptase-positivos foi significativamente maior no interior do infiltrado inflamatório do que na derme não ocupada pelo infiltrado. Em relação aos neuropeptídios não foram encontradas diferenças significativas na imunomarcação dos dois grupos de biópsias. $\mathrm{O}$ aumento relativo de mastócitos triptase-positivos sugere que eles possam estar implicados na deflagração do processo reacional. 0 papel dos neuropeptídios na gênese das reações ainda não pode ser descartado.
\end{abstract}

PALAVRAS-CHAVE: hanseníase, neuropeptídios, mastócitos, triptase, quimase.

\begin{abstract}
Abbreviações: $\alpha$-MSH: hormônio estimulador dos melanócitos- $\alpha$; BB: hanseníase limítrofe; BL: hanseníase limítrofe lepromatosa; CGRP: peptídio com gene relacionado à calcitonina; ENL: eritema nodoso hanseniano; $\gamma$-MSH: hormônio estimulador dos melanócitos-g; IFN- $\gamma$ : interferon-gama; LL: hanseníase lepromatosa; MDT: Poliquimioterapia; SP: substância P; TCMC: mastócitos triptase-quimase-positivos; TIR: Reação tipo I; TIIR: Reação tipo Il; TMC: mastócitos triptase-positivos; TNF- $\alpha$ : fator de necrose tumoral- $\alpha: ;$ VIP: polipeptídio vasoativo intestinal.
\end{abstract}

\footnotetext{
${ }^{1}$ Oswaldo Cruz Institute, Laboratory of Leprosy, Rio de Janeiro, Brazil; ${ }^{2}$ Iguaçu University, Nova Iguaçu, Brazil; ${ }^{3}$ The Experimental Dermatology Unit, Department of Neuroscience, Karolinska Institute, Stockholm, Sweden; ${ }^{4}$ Promega Corporation, Madison, WI, USA. This study was supported by grants from the Fundação de Amparo à Pesquisa do Estado do Rio de Janeiro (FAPERJ), and from the Cancer and Allergy Foundation in Sweden, as well as by funds from the Oswaldo Cruz Institute and from the Karolinska Institute.
}

Received 19 August 2002, received in final form 28 October 2002. Accepted 11 November 2002. 
Leprosy reactions are acute clinical episodes occurring in the chronic course of leprosy. They are classified as type I (TIR) or type II (TIIR; erythema nodosum leprosum $=E N L$ ) reactions ${ }^{1}$. TIR occurs in the borderline patients of the immunopathologic spectrum of the disease ${ }^{2}$. They are interpreted as a shift of the immunologic status towards the tuberculoid pole (upgrading) or towards the lepromatous pole (downgrading) ${ }^{1}$. The increased immune response is characterized by elevated bacillary destruction, appearance of immature tuberculoid granulomas and increased lymphocytic infiltration upon a borderline lepromatous infiltrate, and the presence of edema and vascular congestion. All of these alterations are seen upon the histopathological examination. ENL instead presents a characteristic neutrophilic infiltration over a mononuclear cell infiltrate; edema and cellular disintegration is also exhibited. It also may affect all levels of the dermis and the hypodermis ${ }^{1}$.

Leprosy reactions are a challenging problem because they increase the morbidity of the disease due to nerve damage even after the conclusion of multidrug therapy ${ }^{3}$. Paresthesia, hypoesthesia and paresia become progressively more intense if the treatment is not promptly instituted. An increase in the immune response has been detected in leprosy patients during the reactional episode concomitant with increased levels of TNF- $\alpha$, IL1- $\beta$ and IFN- $\gamma$ and other cytokines in TIR and ENL ${ }^{3-5}$. The presence of $\gamma \delta$-lymphocytes also were detected in the infiltrate of TIR patients with lepromin-induced delayed-type hypersensitivity $^{6}$. Morais et al. ${ }^{7}$, showed an upregulation of IL12 and IFN- $\gamma$ transcripts in both TIR and TIIR. Chemotherapy, pregnancy, intercurrent infections, emotional and physical stress have been identified as predisposing conditions to the reactions ${ }^{3}$. Although all evidence of transient immunologic recovery during the reactional episodes is reported in the leprosy patients, the critical mechanisms which initiates either a TIR or TIIR have not been determined yet.

The immune response is integrated with other systems of the organism on which it is dependent, such as the nervous system and the mast cells. Mast cells are constant cellular components of the dermis, of mucosal lamina proprias, of serosas and of connective tissue in general. Mast cells can produce a great diversity of chemical mediators and are involved in immunoinflammatory responses ${ }^{8}$, antigen presentation $^{9,10}$, anaphylaxis ${ }^{11}$, angiogenesis ${ }^{12}$, and fibrogenesis ${ }^{13}$. The close proximity of mast cells to the peripheral nerve fibers in the tissues ${ }^{14}$ along with the shortening of the distance between mast cells and nerve fibers during inflammatory events ${ }^{12}$, sug- gest a functional interaction between these two components. In addition, mast cells can both produce neuropeptides and be stimulated by them ${ }^{15}$, indicating that neuropeptides could mediate mast cellnerve interactions. Subsets of mast cells are preferentially distributed throughout the connective tissue. The best way to identify mast cell subsets is the analysis of the protease contents in their cytoplasmic granules ${ }^{16,17}$. Basically, there are mast cells which have both tryptase and chymase proteases (TCMC) in their granules, and mast cells which possess tryptase but not chymase $(\mathrm{TMC})^{16}$. The TCMC correspond to the connective tissue mast cells which are present in the dermal compartment of the skin. The TMC are equivalent to the mucosal mast cells and can be found in the peritoneal and mucosal lamina propria ${ }^{12}$.

In leprosy the role of mast cells has not been clearly defined thus far. Rojas-Espinosa and Maldonado ${ }^{18}$ have correlated the increased number of mast cells in the skin of mice experimentally infected with Mycobacterium lepraemurium with the decreased fat tissue observed in these mice. Jayalakshimi and $\operatorname{Lian}^{19}$ and Kontochristopoulos et al. ${ }^{20}$, found a higher number of mast cells in lepromatous than in tuberculoid lesions. Cree et al. ${ }^{21}$, however, have found a higher number of mast cells in tuberculoid than in lepromatous cutaneous lesions. These later authors did not utilize immunohistochemical techniques.

It is broadly accepted that the interaction of the immune system with the nervous system is carried out by means of mediators called neuropeptides ${ }^{22}$. These molecules are produced and released by the nervous system and act on diverse target structures such as vessels, epithelia, anexi, connective tissue cells and lymphocytes. Therefore, neuropeptides add a high degree of complexity to the immunoinflammatory response. Neuropeptides have the capacity to act both as modulators and as effectors of biological processes, widening the interactive network between the nervous and immune systems. Reports about the influence of neuropeptides in the immunoinflammatory process, such as a potentiation of the histamine action ${ }^{23,24}$, inhibition of T cell proliferation, enhancement of chemotaxis for $\mathrm{T}$ cells ${ }^{25}$, induction of mast cell degranulation through histamine release ${ }^{26}$, activation of TNF- $\alpha$ gene transcription ${ }^{27}$, and enhancement of lymphocyte proliferation and IFN- $\gamma$ production $^{28}$, are examples of the participation of neuropeptides in the immunoinflammatory response.

In addition to its effects on pigmentation of the skin, the neuropeptide MSH (melanocyte stimulating hormone), has supressive effects upon macrophage function. It inhibits hypersensitivity reactions and in- 
duces tolerance in murine experimental models ${ }^{29}$. It also regulates keratinocyte proliferation and fibroblast collagenase production ${ }^{29}$. MSH works as a growth factor improving nerve regeneration ${ }^{30-33}$, and acts on neuromuscular junction maturation ${ }^{32}$. However, its role in leprosy has not been evaluated so far.

Our initial hypothesis was that an overproduction and release of neuropeptides could provide the basis for the increased immune response found during leprosy reactions. This speculated imbalance could be caused by the affection of the peripheral nerves by leprosy neuropathy. Mast cells could be involved in the initiation of leprosy reactions as well, because their interaction with nerve fibers through neuropeptide stimulation and/or secretion in the inflammatory process and the release of mediators contained in the granules very probably influence the outcome of the reactional episode.

The objective of this study then, was to compare the number and the distribution of mast cells in biopsies taken in reactional and in post-reactional periods of the leprosy lesions. In addition, the expression of neuropeptides during and after reaction was analysed. The study of the involvement of these two heterogeneous components in the leprosy reaction may help to shed light on the early events leading to TIR and ENL reactions.

\section{METHOD}

Six leprosy patients were selected for this study. Their clinical data are showed in Table 1. These patients had the diagnosis of leprosy confirmed in the leprosy outpatient service of the Oswaldo Cruz Institute. Leprosy patients are usually followed in this service during their treatment and along their post-discharge period. Three patients had TIR and the other three had TIIR. In this study, reactions were analysed as a single group because the number of each type of reaction was low. The procedures for selection of the patients were approved by the Ethics Committee for Research in Humans of Oswaldo Cruz Institute and the patients agreed to participate in the study by signing an enlightened consent term.

The selected patients were submitted to a first skin biopsy during a reactional episode and a second one during remission. The patients were considered to be in remission of the reaction after the reactional lesions had decreased in number or in degree of infiltration and all the general reactional symptoms had subsided. The specific treatment for each kind of reaction (prednisone $1 \mathrm{mg} / \mathrm{kg}$ of body weight/day for TIR and talidomide $200 \mathrm{mg} /$ day for TIIR) was conveniently instituted for each patient.

Half of a six-millimeter cutaneous punch biopsy obtained at both stages of the patient evolution was fixed in a $4 \%$ paraformaldehyde solution containing $14 \%$ of saturated picric acid for two hours at $4^{\circ} \mathrm{C}$, rinsed four times in $0.1 \mathrm{M}$ phosphate buffer with $10 \%$ sucrose added, stored

Table 1. Clinical data of the patients.

\begin{tabular}{|c|c|c|c|c|c|c|c|c|c|c|c|}
\hline Patient & Age & Sex & $\begin{array}{l}\text { Clinical } \\
\text { form }\end{array}$ & MDT & Reaction & $\begin{array}{l}\text { Skin } \\
\text { lesion }\end{array}$ & $\begin{array}{c}\text { Sensorial } \\
\text { impairment }\end{array}$ & Paresthesia & Paresia & $\begin{array}{c}\text { General } \\
\text { symptoms }\end{array}$ & $\begin{array}{c}\text { Time } \\
\text { between } \\
\text { reaction and } \\
\text { remission }\end{array}$ \\
\hline ERS & 29 & M & LL & $\mathrm{MB}$ & TIIR & $\begin{array}{c}\text { Diffuse } \\
\text { infiltration }\end{array}$ & $\begin{array}{l}\text { Shins, } \\
\text { knees, } \\
\text { ankles }\end{array}$ & No & $\begin{array}{l}\text { Intrinsic } \\
\text { muscles of } \\
\text { the hands }\end{array}$ & No & 5 months \\
\hline HJ & 21 & $M$ & $B L$ & $\mathrm{MB}$ & TIIR & $\begin{array}{l}\text { Plaques/ } \\
\text { Nodules }\end{array}$ & No & No & No & No & 1 month \\
\hline JSS & 16 & M & $B L$ & $\mathrm{MB}$ & TIIR & $\begin{array}{c}\text { Plaque } \\
\text { Infiltration } \\
\text { of the ears }\end{array}$ & Hand, feet & $\begin{array}{l}\text { Forearms, } \\
\text { feet }\end{array}$ & $\begin{array}{l}\text { Intrinsic } \\
\text { muscles of } \\
\text { the hands }\end{array}$ & $\begin{array}{l}\text { Edema } \\
\text { of the } \\
\text { ankles }\end{array}$ & 4 months \\
\hline MPC & 63 & $M$ & $B L$ & $\mathrm{MB}$ & TIR & $\begin{array}{l}\text { Plaques } \\
\text { (diffuse) }\end{array}$ & $\begin{array}{l}\text { Shin, } \\
\text { right foot }\end{array}$ & Feet & $\begin{array}{l}\text { Intrinsic } \\
\text { muscles of } \\
\text { the hands }\end{array}$ & $\begin{array}{l}\text { Edema } \\
\text { of the } \\
\text { ankles }\end{array}$ & 1 month \\
\hline MV & 63 & $M$ & BB & $\mathrm{MB}$ & TIR & $\begin{array}{l}\text { Foveolar } \\
\text { plaques } \\
\text { (diffuse) }\end{array}$ & Soles & Right elbow & No & No & 1 month \\
\hline ZAC & 59 & $\mathrm{~F}$ & BL & $\mathrm{MB}$ & TIR & $\begin{array}{l}\text { Plaques } \\
\text { (diffuse) }\end{array}$ & Feet & No & No & No & 5 months \\
\hline
\end{tabular}

$\mathrm{BB}$, borderline borderline patient; $\mathrm{BL}$, borderline lepromatous patient; $\mathrm{LL}$, lepromatous lepromatous patient; $\mathrm{MB}$, multibacillary patient; MDT, multidrug therapy for multibacillary patient; PB, paucibacillary patient; TIR, type I reaction; TIIR, type II reaction. 
Table 2. Paired comparison between TMC/TCMC ratio and the number of mast cells in reactional (R) an post reactional (PR). Wilcoxon Test.

\begin{tabular}{|c|c|c|c|}
\hline \multirow[b]{2}{*}{ Region of The Dermis } & \multicolumn{3}{|c|}{ TMC/TCMC Ratio } \\
\hline & Reactional & Post-reactional & $\mathrm{p}$ value \\
\hline \multicolumn{4}{|l|}{ Means of each region of the dermis } \\
\hline 1. Upper dermis in the infiltrate & $0.390 \pm 0.28$ & $0.181 \pm 0.17$ & 0.04 \\
\hline 2. Middermis in the infiltrate & $0.315 \pm 0.21$ & $0.078 \pm 0.07$ & 0.04 \\
\hline 3. Deep dermis in the infiltrate & $0.540 \pm 0.60$ & $0.190 \pm 0.20$ & 0.24 \\
\hline 4. Upper dermis in the intervening dermis & $0.116 \pm 0.19$ & $0.075 \pm 0.13$ & 1.00 \\
\hline 5. Middermis in the intervening dermis & 0 & 0 & 0.10 \\
\hline 6. Deep dermis in the intervening dermis & $0.021 \pm 0.34$ & $0.031 \pm 0.03$ & 0.6 \\
\hline 7. Whole infiltrate & $0.35 \pm 0.23$ & $0.14 \pm 0.10$ & 0.04 \\
\hline 8. Whole intervening dermis & $0.08 \pm 0.08$ & $0.04 \pm 0.03$ & 0.14 \\
\hline 9. Whole dermis & $0.35 \pm 0.23$ & $0.14 \pm 0.10$ & 0.04 \\
\hline \multicolumn{4}{|l|}{ Estimated number of mast cells $/ \mathrm{mm}^{2}$} \\
\hline 10. Upper dermis in the infiltrate & $3390.9 \pm 2127$ & $2164.0 \pm 1476$ & 0.01 \\
\hline 11. Middermis in the infiltrate & $1497.0 \pm 1064$ & $1162.4 \pm 975$ & 0.53 \\
\hline 12. Deep dermis in the infiltrate & $1050.6 \pm 907$ & $681.6 \pm 887$ & 0.32 \\
\hline 13. Upper intervening dermis & $297.1 \pm 318$ & $368.3 \pm 461$ & 0.91 \\
\hline 14. Mid intervening dermis & $247.3 \pm 115$ & $257.8 \pm 115$ & 0.89 \\
\hline 15. Deep intervening dermis & $201.3 \pm 139$ & $439.0 \pm 625.9$ & 0.46 \\
\hline 16. Whole infiltrate & $19691.3 \pm 5913$ & $14867.7 \pm 9865.4$ & 0.17 \\
\hline 17. Whole intervening dermis & $2047.16 \pm 1157.95$ & $2718.50 \pm 1639.94$ & 0.34 \\
\hline 18. Whole dermis & $21738.5 \pm 5646.7$ & $17585.67 \pm 10520.52$ & 0.2 \\
\hline
\end{tabular}

in liquid nitrogen, and sectioned on a Microm cryostat (Heidelberg, Germany). The sections were thawed onto pre-coated glass slides (Super FrostÒPlus, Menzel-Gläser, Braunschweig, Germany). The other half was processed for routine paraffin embedding for diagnostic purposes.

Both biopsies (reactional and post-reactional) of each patient were processed in parallel for the immunostaining of neuropeptides and mast cell markers. Single (for neuropeptides) and double-staining (for mast cells) with indirect immunofluorescence methods were utilized.

The primary antibodies to neuropeptides selected for this study were rabbit anti-calcitonin gene-related peptide (anti-CGRP, 1:600 Peninsula Laboratories, Inc.Belmont, CA, USA), anti-vasoactive intestinal polypeptide (anti-VIP, 1:200, Peninsula Laboratories, Inc, Belmont, CA, USA), antisubstance $P$ (anti-SP, 1:400, Chemicon International Inc., Temecula CA, USA), anti- $\alpha$-melanocyte stimulating hormone (anti- $\alpha-\mathrm{MSH}, 1: 400$, Chemicon International Inc., Temecula CA, USA), and anti- $\gamma$-melanocyte stimulating hormone (anti- $\gamma$-MSH, 1:400, Chemicon International Inc., Te- mecula CA, USA) each diluted in $0.01 \mathrm{M}$ phosphate buffer containing $0.3 \%$ Triton $X-100$. The sections were incubated overnight at $4^{\circ} \mathrm{C}$ in a humid chamber followed by incubation for $30 \mathrm{~min}$ at $37^{\circ} \mathrm{C}$ with lissamine rhodamine (LRSC)conjugated donkey anti-rabbit IgG antiserum (Jackson ImmunoResearch Laboratories, West Grove, PA, USA), diluted 1:160 in the same buffer as the primary antibodies.

The primary antibodies for the double-staining of mast cell enzymes were mouse anti-chymase $(1: 2,000$, Chemicon International Inc. Temecula, CA, USA) and chicken antitryptase (1:200, Promega Corporation, Madison, WI, USA). The sections were incubated with both primary antibodies overnight at $4^{\circ} \mathrm{C}$ in a humid atmosphere, followed by the incubation of fluorescein isothyocyanate (FITC)-conjugated donkey anti-mouse (1:160, Jackson ImmunoResearch Laboratories, West Grove, PA, USA) together with LRSCconjugated donkey anti-chicken (1:160, Jackson Immuno Research Laboratories, West Grove, PA, USA). Both conjugates were diluted in $0.01 \mathrm{M}$ phosphate buffer containing $0.3 \%$ Triton $\mathrm{X}-100$. 
Tabela 3. Comparisons.

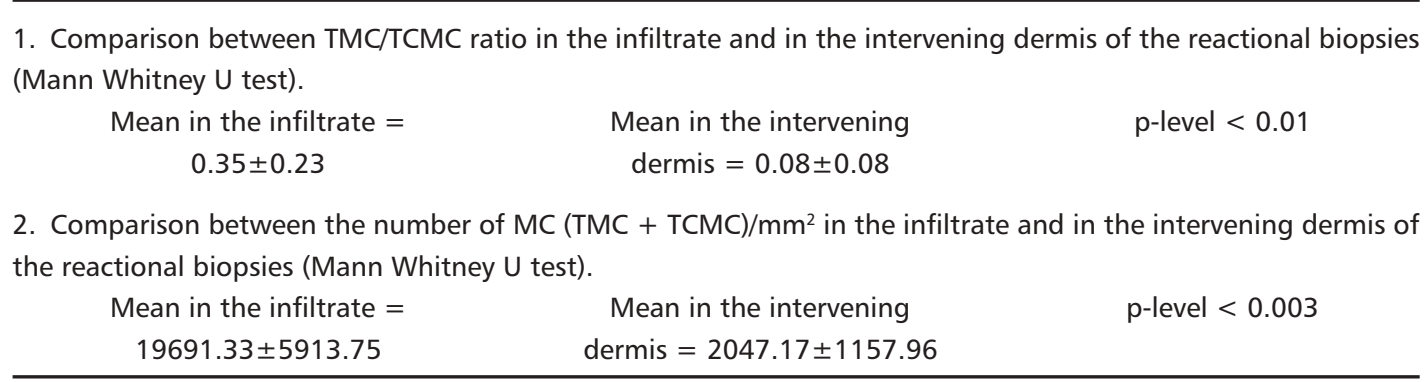

Significant $\mathrm{p}$-values are less than 0,05 .

Table 4. Comparisons.

1. Comparison between TMC/TCMC ratio in the infiltrate and in the intervening dermis of the post-reactional biopsies (Mann Whitney U test)

$\begin{array}{ccc}\text { Mean in the infiltrate }= & \text { Mean in the intervening } & \text { p-level }<0.04 \\ 0.14 \pm 0.104 & \text { dermis }=0.04 \pm 0.04 & \end{array}$

2. Comparison between the number of $\mathrm{MC}(\mathrm{TMC}+\mathrm{TCMC}) / \mathrm{mm}^{2}$ in the infiltrate and in the intervening dermis of the post-reactional biopsies (Mann Whitney $U$ test)
Mean in the infiltrate $=$
Mean in the intervening
p-level $<0.009$

$14867.17 \pm 9865.416$

dermis $=2718.50 \pm 1639.94$

Significant $p$-values are less than 0,05 .

Control sections were incubated with corresponding normal sera instead. The observation was performed using different excitation lights with a photomicroscope (Nikon, Tokyo, Japan). The immunohistochemical expression of neuropeptides and mast cell markers were compared in both types of biopsies.

Indirect immunofluorescence with rabbit anti-human PGP 9.5 antibody was utilized to stain the cutaneous nerve fibers of biopsies from both groups. The estimated amount of PGP 9.5-positive fibers was a basis for comparison with immunoreactivity obtained with the anti-neuropeptide antibodies listed above.

The stained mast cells were counted in the inflammatory infiltrate and in the intervening dermis. This was possible because the area occupied by the inflammatory infiltrate could be clearly distinguished from the non-affected dermis in the immunostained sections. In the former, a sharp demarcated area of distinct colour and homogeneous matrix was observed; in the latter, collagen bundles intermingled with elastic fibers could be identified. The frame utilized for taking microphotographs was employed as a standard field for counting mast cells. The mast cells inside twelve frames (six placed on the cross-sectional area occupied by the inflammatory infiltrate and six placed on the region of intervening dermis) per section were counted. The frames were placed on the section so that the inflammatory infiltrated area and the intervening dermis of the upper, the middle and the deep dermis were counted separately. Two non-adjacent sections for each biopsy were picked for the counting. The objective lens utilized was the 20X objective matched with a 10X ocular.
An estimated number of mast cells per $\mathrm{mm}^{2}$ was obtained counting the mast cells along the $0.5 \mathrm{~mm}$-standard inner side of the frame twice to the square.

The total amount of counted mast cells (TMC + TCMC) in the inflammatory infiltrate, in the intervening dermis of the upper, middle and deep regions and in the whole dermis were determined. A TMC / TCMC ratio was determined in the inflammatory infiltrate and in the unaffected dermis (upper, mid, deep and the whole dermis).

Paired comparisons of the numbers of mast cells and the TMC /TCMC ratio in both reactional and in post-reactional biopsies utilizing Wilcoxon's test non-parametric paired analysis are listed in Table 2. The comparison between TMC/TCMC ratios and the total amount of mast cells in the infiltrate and in the intervening dermis within each group utilizing the Mann Whitney $\mathrm{U}$ test is shown in Tables 3 (reactional group) and 4 (post-reactional group).

The Statistica 6.0 software (Statsoft Inc., USA) was employed for the statistical analysis.

\section{RESULTS}

All the six biopsies taken during the reactional episode (TIR and TIIR) showed an inflammatory infiltrate compatible with the clinical picture. (Figs 1a and 2a). Although the lesions in the remission of the reaction were without infiltration at the clinical examination, the inflammatory infiltrates remained within their dermal extension at the histopathological observation (Figs $1 b$ and $2 b$ ). The area on the section occupied by the inflammatory infiltrate in 


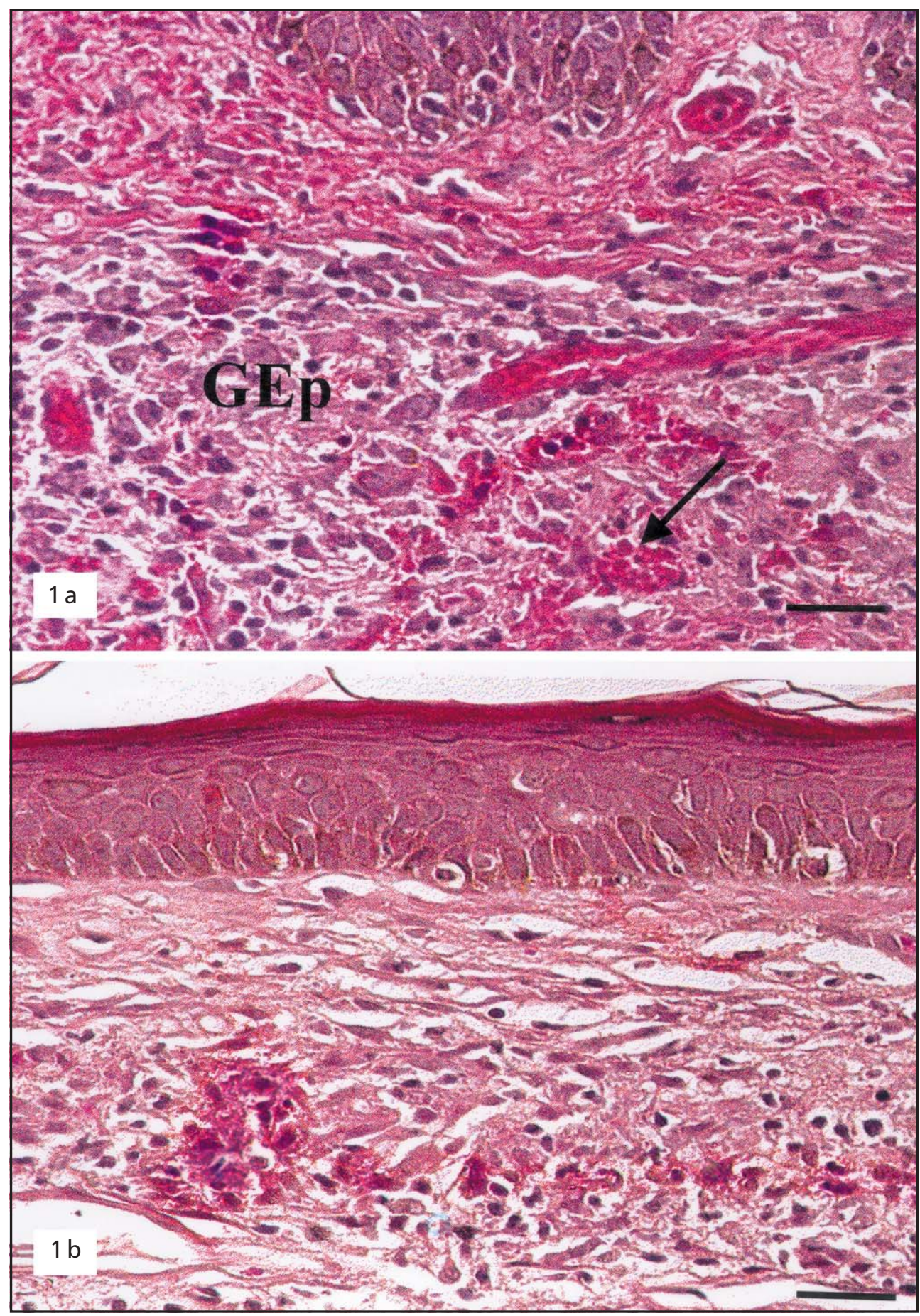

Fig 1. (a) An upgrading reaction in a BL (borderline lepromatous patient). Note the epithelioid granuloma (Gep) with edema, congestion and a hemorragic area (arrow) in the reactional biopsy. (b) Biopsy of the same patientt after remission of the clinical symptoms. The edema and vascular congestion subsided, but the epithelioid infiltrate still remained in the dermis. Scale bars: $15 \mu \mathrm{m}$.

the post-reactional biopsies was still large enough to allow the quantification of mast cells in the infiltrate of these biopsies (Figs $1 \mathrm{~b}$ and $2 \mathrm{~b}$ ).

The number of mast cells $/ \mathrm{mm}^{2}$ in the whole dermis of reactional and post-reactional biopsies were not significantly different (Fig 3a, 3b and Table 2, line 18), except in the upper inflammatory infiltrate, which revealed a significantly higher number in the reactional lesions (Table 2, line 10). The TMC/TCMC ratio in the inflammatory infiltrate (Figs $4 a, 4 b$, Table 2 , lines $1,2,7,9)$, but not in the intervening dermis (Table 2, lines $4,5,6,8$ ) was significantly higher in 


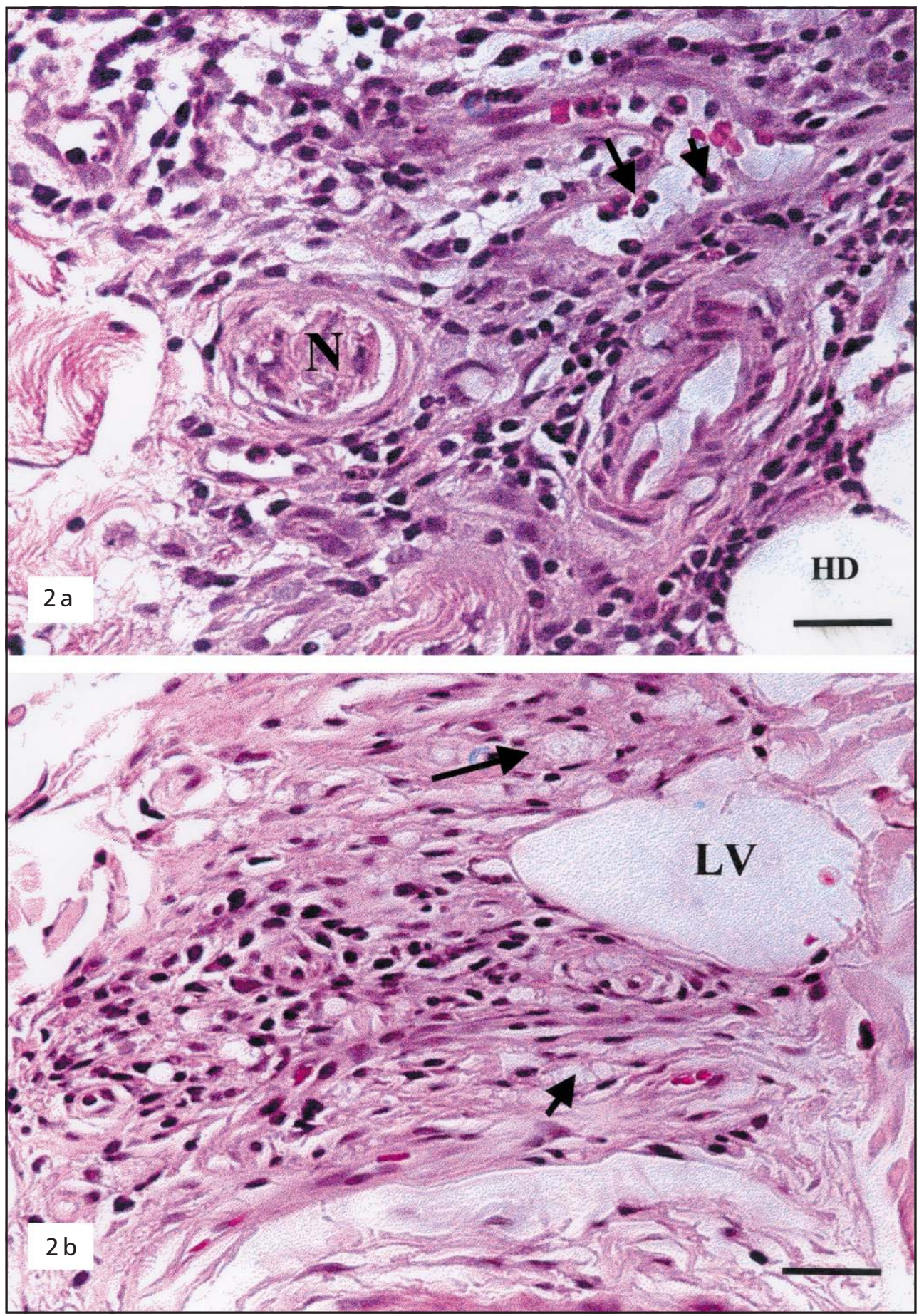

Fig 2. (a) Erythema nodosum leprosum in a BL patient. Note the mononuclear infiltrate with marginating neutrophils attached to vascular walls (arrows) in the deep dermis. HD: hypodermis. (b) The biopsy after the remission of the reaction shows less inflammatory infiltration and grossly vacuolated cells macrophages (arrows). Dilated lymphatic vessel (LV) is also seen. Scale bars: $15 \mu \mathrm{m}$.

the reactional biopsies than in the post-reactional ones. In both reactional (Table 3, lines 1, 2) and postreactional biopsies (Table 4, lines 1,2), the TMC/TCMC ratio and the number of mast cells (Fig 5) were significantly higher in the inflammatory infiltrate than in the intervening dermis.
The amount of the CGRP-, VIP-, SP-, $\alpha-\mathrm{MSH}-$, and $\gamma$-MSH-immunoreactive nerve fibers was very low or negative in both reactional and post-reactional biopsies so that their quantification was not performed. CGRP-positive fibers could be observed in both biopsies of each patient, but in a small amount in the 


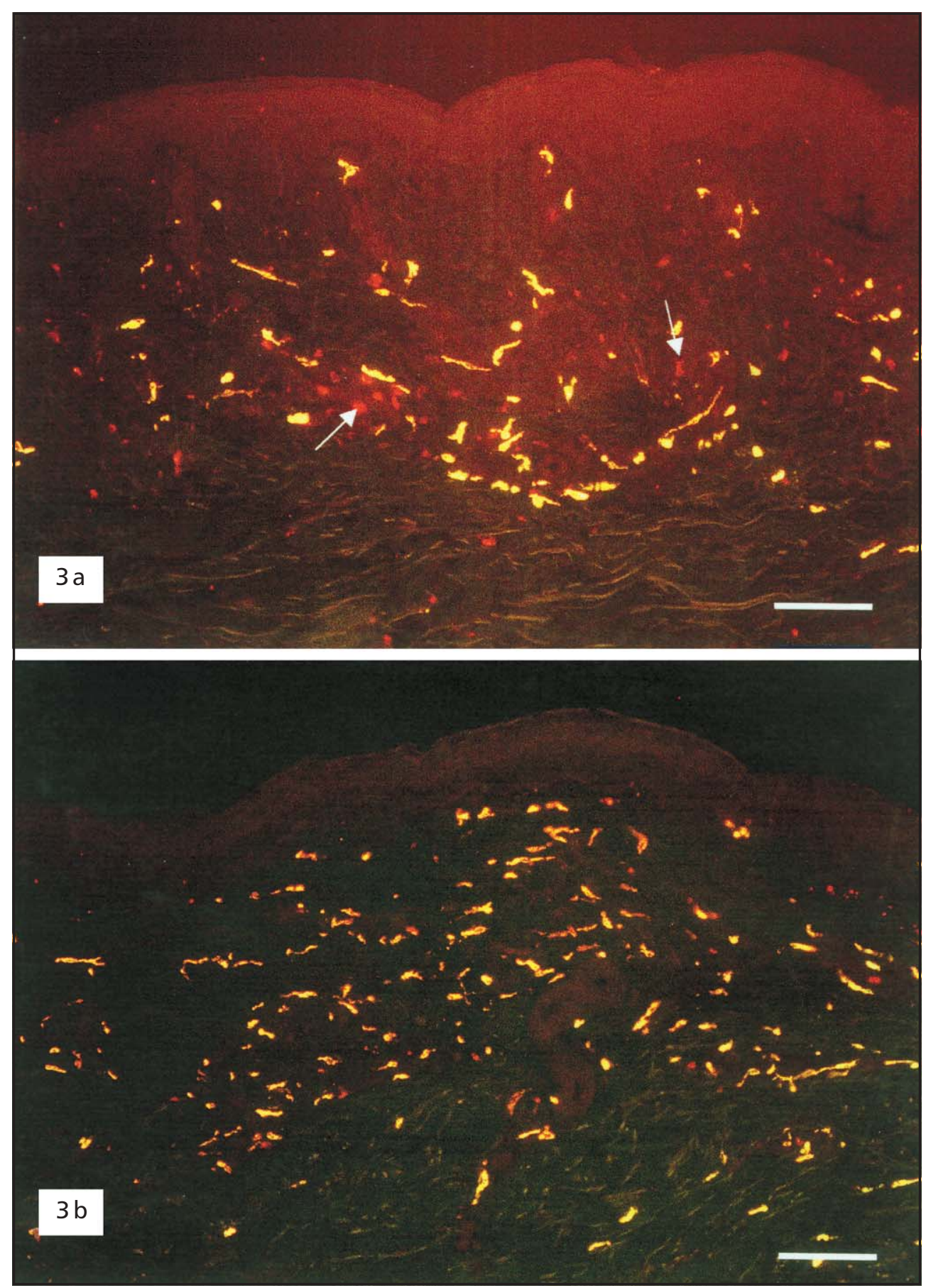

Fig 3. TCMC (yellow-green color) and TMC (orange color) in a reversal reaction episode (a) and in the remission reactional biopsy (b). Double-labeling with indirect immunofluorescence. The TMC/TCMC ratio is higher in the whole dermis of the reactional biopsy. Scale bars: $50 \mu \mathrm{m}$.

subepidermal region. VIP-positive fibers were found surrounding sweat gland accini and some vessels in both reactional and post-reactional biopsies. $\alpha-\mathrm{MSH}-$ and $\gamma$-MSH-immunoreactive nerve fibers were not seen in the dermis of the reactional and post-reactional episodes. The CGRP- and VIP-positive fibers were found only outside of the inflammatory infiltrates. PGP 9.5- immunoreactive fibers were present in the intervening dermis, beneath the epidermis, surrounding sweat glands and anexial structures but were very scarce in the inflammatory infiltrate in both R and PR groups. They were present in higher amount than the neuropeptide immunoreactive fibers stained with the antibodies utilized in this study. 


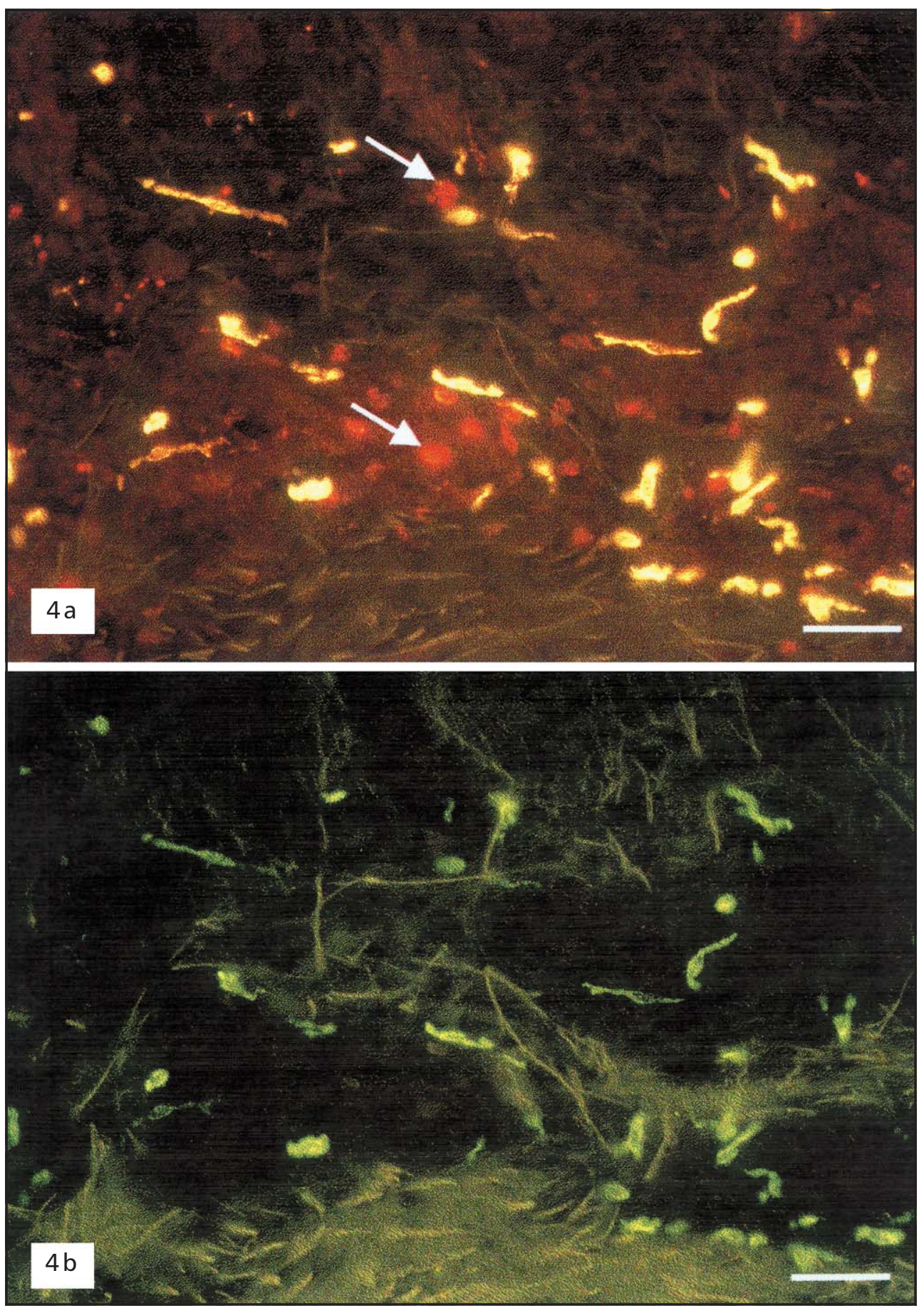

Fig 4. (a) TCMC (yellow-green color) and TMC (orange color) in the inflammatory infiltrate of a reversal reaction biopsy. Some TMC are marked with arrows. (b) Same field of the figure (a). The TMC which were marked with arrows in (a) have disappeared because with this excitation light only chymaseimmunoreactive mast cells are visualized. Double-labeling with anti-tryptase and anti-chymase, Indirect immunofluorescence. Scale bars: $15 \mathrm{~mm}$.

\section{DISCUSSION}

In this study, the expression of neuropeptides and the presence of tryptase/chymase- and tryptase-immunoreactive mast cells in the reactional lesions and in the post-reactional biopsies was demonstrated. Our findings support the hypothesis that mast cells might be involved in early events leading to the increased immunoinflammatory response during leprosy reactions reported in the literature. This correlation suggests a possible starting mechanism of the reactional episode, which remains to be further clarified. 


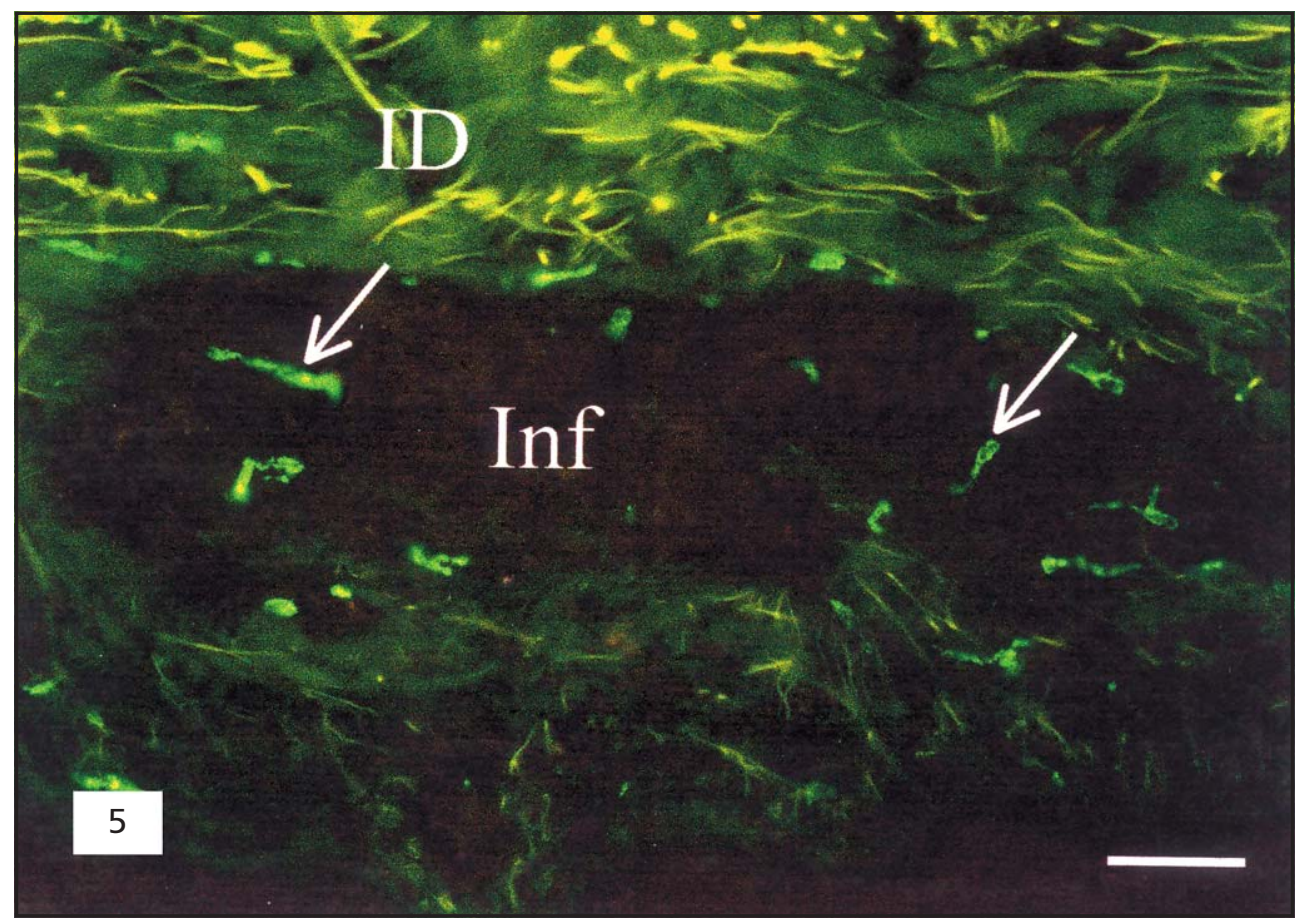

Fig 5. The amount of chymase-positive mast cells is somewhat higher in the reactional inflammatory infiltrate (inf) than in the intervening dermis (ID) of a reactional biopsy. Anti-chymase, indirect immunofluorescence. Scale bar: $15 \mu \mathrm{m}$.

The quantitative results regarding neuropeptidepositive nerve fibers in the reactional and post-reactional biopsies was below our initial expectations. We expected increased levels of neuropeptide expression, because our initial hypothesis was that excessive production and release of neuropeptides due to a possible imbalance could be one of the critical factors for the stimulation of the inflammatory response. This study has, however, not shown any difference between the neuropeptide expression by nerve fibers present in the reactional and post-reactional inflammatory infiltrate, so that a relationship between any alteration of neuropeptide expression and the appearance of reaction could not be characterized, at least not from morphological point of view while using the present markers. The presence of any extracellular neuropeptide-positive material was not found either. In fact, the presence of neuropeptide-immunoreactive nerve fibers was not found in the inflammatory infiltrate, nor in the unaffected dermis. Although the findings in this study do not provide evidence of a role for neuropeptide in the triggering of leprosy reactions, we do not preclude the participation of neuropeptides as a critical causative factor for leprosy reactions, as neuropeptides are secreted in very low amounts by the peripheral nerve fibers and differences might not be detected by immunohistochemical methods. In addition, a great part of the termi- nal nerve fibers are destroyed by the inflammatory lesions of the reactions, so that the presence of neuropeptide-positive fibers would be difficult to detect, especially in the inflammatory infiltrate.

Mast cells have important biological roles in the inflammatory process and in the stimulation of the immune response. Therefore, an estimation of their presence in the infiltrate using proper immunohistochemical staining method has also been our goal, suitable to the objectives of this investigation.

At first, we expected that the number of mast cells would be considerably higher in the reactional lesions due to the inflammatory infiltration which by itself, increases the number of these cells. However, the number of mast cells in the post-reactional infiltrate showed no significant decrease but was still high, except in the infiltrate of the upper dermis. This elevated number of mast cells after the reaction had subsided could be explained through a mast cell participation in the inflammatory dermal repair, which occurrs in this healing period, and/or by a low turn-over of the mast cell population in these tissues.

The significantly higher TMC /TCMC ratio in the reactional infiltrate compared with the one in the post-reactional inflammation is an evidence for a qualitative modification in the mast cell population. The relative increase of TMC is a change in the pro- 
portion of the mast cell subsets in the dermis, which in the normal dermis is mainly occupied by the TCMC, with a small number of $\mathrm{TMC}^{12}$. This minor subset plays an important role in the stimulation of a T cell response which is known to occur during any kind of reaction. So, in a speculative way, we could implicate this increased number as a participation of the TMC subset in the increased immunoinflammatory response observed in the reactional episodes.

The higher amount of the total mast cells, and the higher TMC /TCMC ratio in the inflammatory infiltrate compared to the intervening dermis, displayed in both reactional and post-reactional biopsies, are very likely a consequence of the reactional inflammation. So, it probably occurs secondary to the inflammation establishment, because no significant difference regarding these two parameters was found between the intervening dermis of the reactional and post-reactional biopsies and also among the distinct regions of the intervening dermis studied inside of each group. In addition, a higher total mast cell number, and/or an increase of their subsets, would be expected in the intervening dermis of the reactional biopsies if they preceded the reactional inflammation. Together these are evidences that variations on the mast cell population occurs on account of the inflammatory process.

The patients of this study were still under treatment (corticotherapy in TIR and talidomide for ENL) at the time of the second biopsy after the clinical remission of the reaction. Interestingly, corticotherapy seems not to reduce significantly the total number of mast cells in the post-reactional biopsies. The comparison of the mast cell population and their subsets in each type of reaction (type I and type II) was not possible because we had only three patients from each. The small size of the sample would invalidate any optimal statistical comparison. However, the results obtained in this study have encouraged us to investigate the morphological and functional aspects of mast cell population in each type of leprosy reaction. It is worth noting that reaction in leprosy can be assessed as an event of a single nature or essence with different forms of presentation depending on the patients' immunological status. This was the way we assessed reaction and mast cells in this investigation.

Our experiments controlled cutaneous regional variations in mast cell quantification, utilized a precise method for identification of mast cells and their subsets with anti-tryptase and anti-chymase and took into account the density of mast cells (number of mast cells $/ \mathrm{mm}^{2}$ ) and their TMC/TCMC ratio. Data in the literature on the role of mast cells in leprosy do not provide clear points of view about this subject. We think the difficulty to achieve them is due to the diverse methods of identification and protocols of quantification utilized. We recently have found the report of Mahaisavariya et al..$^{34}$ in which the authors show the number of mast cells in biopsies taken on the diagnosis (the first) and during the reactional episode (the second). The protocols used for staining and quantification of mast cells, schedule for taking biopsies, the number of patients were different from the utilized in our study. Qualitative change of mast cells (subset alterations) in reaction was the main objective of the present investigation, so that is why confrontation of our results with the quoted paper is also difficult.

We conclude that the relative increase of TMC found in this study is related to the reactional episodes of leprosy. The real role of this cutaneous mast cell subset in the mechanism of leprosy reaction remains to be elucidated. Other comparisons performed which showed no significant statistical difference (number of total mast cells in the reactional and post-reactional groups) require a higher number of patients to achieve a definite conclusion. Alterations in the numerically few neuropeptide-immunoreactive structures associated with the reactional episodes could not be detected with the presently employed immunohistochemical methods.

Acknowledgements - We also express our thanks to Haroldo Matos, Department of Computer Science, State University of Rio de Janeiro, Brazil. Ms Agnetha Bonnevier and Ms Eva-Karin Johansson are gratefully acknowledged for skilful technical and secretarial assistance.

\section{REFERENCES}

1. Bryceson A, Pfaltzgraff RE. Immunological complications: reactions. In Leprosy. Medicine in the tropics. Edingburgh: Churchill Livingstone 1990:115-126

2. Sehgal VN, Srivastava G, Sundharam JA. Immunology of reactions in leprosy: current status. Int J Dermatol 1988;27:157-162.

3. Lienhardt C, Fine PEM. Type I reaction, neuritis, and disability in leprosy. Lepr Rev 1994;65:9-33.

4. Yamamura M, Uyemura K, Deans RJ, et al. Defining protective responses to pathogens: cytokine profiles in leprosy lesions. Science 1992;254:277-282

5. Sarno EN, Grau GE, Vieira LMM, Nery JA. Serum levels of tumor necrosis factor-alpha and interleukin-1 $\beta$ during leprosy reactional states. Clin Exp Immunol 1991;84:103-108.

6. Uyemura K, Band H, Ohmen J, Brenner MB, Rea TH, Modlin RL. $\gamma \delta$ T cells in leprosy lesions. Curr Top Microbiol Immunol 1991;173:203-207.

7. Moraes MO, Sarno EN, Almeida AS, et al. Cytokine m RNA expression in leprosy: a possible role for interferon- $\gamma$ and interleukin-12 in reactions (RR and ENL). Scand J Immunol 1999;50:541-549.

8. Wershil BK, Murakami I, Galli SJ. Mast cell dependent amplification of an immunologically nonspecific inlammatory response. J Immunol 1988;140:2356-2360. 
9. Fox CC, Jewell SD, Whitacre CC. Rat peritoneal mast cells present antigen to a PPD specific T cell line. Cell Immunol 1994;158:253-264.

10. Frandji P, Oskerititzian F, Cacaraci F, et al. Antigen-dependent stimulation by bone marrow-derived mast cells of MHC class II restricted T cell hybridoma. J Immunol 1993;151:6318-6328.

11. Stevens RL, Austen KF. Recent advances in the cellular and molecular biology of mast cells. Immunol Today 1989;10:381-383.

12. Metcalfe DD, Baram D, Yoseph AM. Mast cells. Physiol Rev 1997;77:1033-1079.

13. Brewster CEP, Howarth PH, Kjukanovic R, Wilson J, Holgate ST, Roche WR. Myofibroblasts and subepithelia fibrosis in bronchial asthma. Am J Res Cell Mol Biol 1990;3:507-511.

14. Stead RH, Tomioka M, Quinonez G, Simon GT, Felten SY, Bienenstock J. Intestinal mucosal mast cells in normal and nematode-infected rat intestines are in intimate contact with peptidergic nerves. Proc Natl Acad Sci USA 1987;84:2975-2979.

15. Levi-Schaffer F, Shalit M. Differential release of histamine and prostaglandin $\mathrm{D}_{2}$ in rat peritoneal mast cells activated with peptides. Int Arch Allergy Immunol 1989;90:352-357.

16. Irani AMA, Bradford TR, Kepley CL, Schechter NM, Schwartz LB. Detection of MCT and MCTC types of human mast cells by immunohistochemistry using new monoclonal antitryptase and antichymase antibodies. J Histochem Cytochem 1989;37:1509-1515.

17. Irani AM, Schwartz LB. Human mast cell heterogeneity. Allergy Proc 1994;15:303-308.

18. Rojas-Espinosa $\mathrm{O}$, Reyes Maldonado E. Cutaneous lipids and mast cells in murine leprosy. Int J Lepr 1991;59:325-331.

19. Jayalakshmi P, Lian TK. Mast cells in lepromatous leprosy. Int J Lepr 1995;63:291-292.

20. Kontochristopoulos G, Liossi A, Panteleos D. An investigation of mast cells in two basic leprosy groups. Int J Lepr 1993;61:634-635.

21. Cree IA, Coghill G, Beck S. Mast cells in leprosy skin lesions. J Clin Pathol 1990;43:196-200.
22. Rossi R, Johansson O. Cutaneous innervation and the role of neuronal peptides in cutaenous inflammation: a minireview. Eur J Dermatol 1998;8:299-306.

23. Brain SD, Williams TJ. Interactions between the tachykinins and calcitonin gene-related peptide lead to the modulation of oedema formation and blood flow in rat skin. Br J Pharmacol 1989;97:77-82.

24. Brain SD, Cambridge H, Hughes SR, Wilsoncroft P. Evidence that calcitonin gene-related peptide contributes to inflammation in the skin and joint. Ann NY Acad Sci 1992;657:412-418.

25. Foster CA, Mandak B, Kromer E, Rot A. Calcitonin gene-related peptide is chemotactic for human T lymphocytes. Ann NY Acad Sci 1992;657:397-404.

26. Ebertz JM, Hirshman CA, Kettelkamp NS, Uno H, Hanifin JM. Histamine release from mast cells. J Invest Dermatol 1987;88:682-685.

27. Ansel JC, Brown JR, Payan DG, Brown MA. Substance P selectively activates TNF-alpha gene expression in murine mast cells. J Immunol 1993;150: 4478-4485.

28. Wagner F, Fink R, Hart R, Cancygier H. Substance P enhances interferon-gamma production by human peripheral blood mononuclear cells. Regul Pept 1987;19:355-364.

29. Luger TA, Scholzen T, Grabbe S. The role of a-melanocyte stimulating hormone in cutaneous biology. J Invest Dermatol 1997;2:87-93.

30. Edwards PM, Kuiters RR, Boer GJ, Gispen, WH. Recovery from nerve transection is accelerated by local application of a-MSH. J Neurol Sci 1986;74:171-176.

31. Verhaagen J, Edwards PM, Jennekens FG, Gispen WH. Pharmacological aspects of the influence of melanocortins on the formation of regenerative peripheral nerve sprouts. Peptides 1987;8:581-584.

32. Strand FL, Zuccarelli LA, Williams KA, et al. Melanotropins as growth factors. Ann NY Acad Sci 1993;680:29-50.

33. Dekker AJ. Effect of a-melanocyte stimulating hormone on peripheral nerve regeneration in the rat: histological aspects and comparison with the effect of gangliosides. Exp Neurol 1988;99:490-497.

34. Mahaisavariya P, Jiamton S, Manonukul J, Khemngern S. Mast cells in leprosy and leprosy reactions. Int J Dermatol 2000;39:274-277. 